Original research article

\title{
Effect of the 'Enhanced Recovery After Surgery Protocol' on the workload of nurses in cardiac patients
}

\author{
Sabina Krupa, Dorota Ozga *, Maciej Kolowca, Kazimierz Widenka \\ University of Rzeszow, College of Medical Sciences, Rzeszow, Poland
}

\begin{abstract}
The aim of the study was to compare the workload of nurses in patients after cardiac surgery with minimal access, anaesthesia standard and according to the 'Enhanced Recovery After Surgery Protocol' (ERAS protocol). A quantitative descriptive design was used. The study included a group of 100 patients with mitral valve disease in a Cardiac Surgery Intensive Care Unit (ICU) in Poland. The research project lasted 7 months. The nurses' workload was assessed in accordance with the guidelines of NAS scale. The average age of cardiac surgery patients studied was $54.9 \pm 14.38$. In the studied group of cardiac surgery patients there were $48 \%$ women and $52 \%$ men.

The average workload of nurses in the ERAS group in NAS scoring on day 0 of daily duty was $67.5 \pm 2.97$. The average workload of nurses in the ERAS group in NAS scoring on day 1 of daily duty was $48.6 \pm 2.85$. The average workload of nurses in the ERAS group in NAS scoring on day 2 of daily duty was $48.6 \pm 2$. Patients who were anesthetised according to the ERAS protocol required less labour than standard anesthetised patients. The workload for patients anaesthetised according to the ERAS protocol is lower compared to the workload on standard anesthetised patients.
\end{abstract}

Keywords: ERAS protocol ('Enhanced Recovery After Surgery Protocol'); NAS (Nursing activities score); nurses

\section{Introduction}

Intensive Care (IC) is not only associated with treatment, but also with intensive nursing care. It is based on 24-hour observation and analysis of the dynamics of clinical changes in the patient's condition. The activities carried out by nurses are independent and characteristic of this profession. Whenever dependent activities are mentioned, this means activities involving the execution of physicians' orders and requests. Co-dependent activities include cooperation with members of an interdisciplinary team (Wołowicka and Dyk, 2001). While both the TISS-28 (Therapeutic Intervention Scoring System) and NEMS (Nine equivalents of nursing manpower use score) scales have been adapted to Polish working conditions, they are not used universally in everyday clinical practice (Miranda et al., 1996; 1997, Wysokiński, 2006). In 2003, Miranda et al. were the first in the world to develop a tool to assess the workload of a nurse (NAS - Nursing Activities Score). During the research on that scale, it was proven that it is not complicated and can be used to estimate the need for nursing care on each duty. According to the authors of the study, the workload of nurses is related to the quality of patient care and health of employees (Aiken et al., 2012; 2014; Bray et al., 2010; Kane et al., 2007; Numata et al., 2006). Before the introduction of the NAS scale in 2003, the TISS scoring system was used. NAS has been validated in 99 Intensive Care Units (ICU) in 15 countries (Cullen et al., 1974; Keene and Cullen, 1983; Miranda et al.,
1996; 1997; 2003). The quality of care is determined by many factors, including human resources and staff qualifications. The qualifications in question are necessary for the proper performance of one's duties at the workplace. There are no legal regulations in Poland that provide a detailed specification of the ICU nursing staff. In our daily work we do not encounter the use of special tools for the purpose of planning the nursing staff. The research on the planning of nursing manpower has given rise to the idea of developing tools which should allow every ICU to estimate its staffing needs (Miranda et al., 1996; Smereka and Kiibler, 1998; Wysokiński, 2006;). Many studies have shown that insufficient number of nurses has an adverse impact on mortality, infections and general patient safety ( $\mathrm{Ai}$ ken et al., 2002; Rafferty et al., 2007; Seago et al., 2006; Zingg et al., 2015). The aim of the study was to compare the workload of nurses in patients after cardiac surgery with minimal access, anaesthesia standard and according to the ERAS protocol.

\section{Materials and methods}

\section{Design and participants}

The NAS (Nursing activities score) scale is used to assess the workload of nurses in terms of demand for nursing care in intensive care units (Miranda et al., 2003). This scale was developed by a team of scientists who had previously conducted their research on TISS-28 and NEMS score systems. The NAS scale allows one to examine the time a nurse spends on patient

\footnotetext{
* Corresponding author: Dorota Ozga, University of Rzeszow, College of Medical Sciences, Institute of Health Sciences, St. Warzywna 1A, 35-310 Rzeszow, Poland; e-mail: gdozga@poczta.fm http://doi.org/10.32725/kont.2020.030 
care and administrative activities. According to the authors, nurses devote $43.3 \%$ of their time to activities covered by the TISS-28 scale. It was noted that $34.4 \%$ of nurses' activity was not included in the mother scale. In order to fully describe nursing activities, an attempt was made to analyse those activities that are missing on the TISS-28 scale. As a result, a team of experts from 15 Western European countries was set up to specify the tasks typically performed by ICU nurses. This, in turn, has brought the NAS scale of nursing activities into existence. This scale allows us to describe $81 \%$ of nursing time (i.e. twice as much as the TISS-28 scale) (Miranda et al., 2003).

The study included a group of 100 patients - 50 under standard anaesthetisation and 50 anaesthetised according to the Enhanced Recovery After Surgery Protocol (ERAS) (Suppl. 1). Both groups of patients were hospitalised in the Department of Intensive Cardiac Surgery Care after minimal access valve surgeries, from 1 November 2017 to 31 May 2018. During the study on the nurses' workload, 38 nurses working in the Department of Intensive Cardiac Surgery Care were invited to participate in the study. Patients who qualified for the study were selected alternately - one patient was qualified for ERAS anaesthesia and another for standard anaesthesia. Both patients and nurses received a form to give informed consent for participation in the study. The study was prospective. Nurses were also selected randomly, depending on the duty performed. During working hours they filled in the documentation (once during duty), which included NAS scale. The NAS scale is used as a standard for patient documentation in the Department of Cardiac Surgery. After each duty shift, the number of points collected in all patients in the ward was recorded, and the points were then summed up and divided by the number of nurses working on a given shift.

\section{Data collection}

The study included a group of 100 patients - 50 were administered standard anesthesia and 50 were anaesthetized according to the ERAS protocol. Both groups of patients were hospitalized in the Department of Cardiac Surgery Intensive Care after a valve surgery with minimal access, from November 1, 2017 to May 31, 2018. The table below shows the main differences between the anesthesia protocols. Reporting of the study findings adheres to the CONSORT checklist; see Suppl. 2.

\section{Ethical approval}

The research was conducted in accordance with Resolution No. 2018/04/04/04 of the University of Rzeszów Bioethics Committee.

\section{Results}

\section{General characteristics}

The study group consisted of 100 patients after a cardiac surgery in the ICU ward; half of which had been anaesthetised according to the ERAS protocol and another half anaesthetised in line with the standard procedure. The description was carried out separately for each patient group. In the studied group of cardiac patients, $48 \%$ were women and $52 \%$ men. The distribution of women and men in groups of patients anaesthetised with the ERAS protocol and standard procedure was similar $\left(\chi^{2}=0.16 ; p=0.68\right)$. The differences, however, were not statistically significant. The age of all patients in the study group was from 18 to 81 years with a range of 63 years. The mean age of cardiac patients was $54.9 \pm 14.38$. The median age in the analysed group was 57 years. In this case, statistical significance was demonstrated. In the studied group of cardiac patients, most people (29\%) had hypertension, while $18 \%$ suffered from diabetes, and a similar distribution was observed among patients anaesthetised with various methods. This distribution was not statistically significant. The distribution of hypercholesterolemia in the group of patients anaesthetised with the ERAS protocol was 20\%; in the group of patients anaesthetised using standard measures it was significantly lower at $6 \%$ $\left(\chi^{2}=4.54, p=0.03\right)$ and statistically significant. Nicotinism was observed in $12 \%$ of cardiac patients and a similar distribution was found in both analysed groups of these patients. This distribution was not statistically significant. The distribution of risk factors in cardiac patients, ERAS-anaesthetised patients and patients anaesthetised using standard measures was similar $\left(\chi^{2}=6.32, p=0.09\right)$, with no statistical significance shown.

\section{Patient characteristics}

The age of patients anesthetized with the ERAS protocol of the study group ranged from 18 to 78 years - with a range of 60 years. The mean age of cardiac surgery patients anesthetized with the ERAS protocol was $51.7 \pm 14.24$. Half of the examined cardiac surgery patients anesthetized with the ERAS protocol were between 42 and 64 years old, and the median age of the examined cardiac surgery patients anesthetized with the ERAS protocol in the group was 55 years. Statistical significance was demonstrated at this level. The age of standard anesthetized patients was between 18 and 81 years - with a range of 63 years. The standard age of anesthetized cardiac surgery patients was $58.2 \pm 13.93$. The median age of the patients undergoing cardiac surgery anesthetized as standard in the group was 59 years - and this is statistically significant.

In the studied group of cardiac surgery patients, most people (29\%) had hypertension, $18 \%$ suffered from diabetes, and a similar distribution was found among patients anesthetized by various methods. This distribution was not statistically significant. The distribution of hypercholesterolemia in the group of patients anaesthetized with the ERAS protocol was $20 \%$, and in the group of patients with anesthesia, it was significantly lower, $6 \%\left(\chi^{2}=4.54, p=0.03\right)$ and statistically significant. Nicotinism affected $12 \%$ of the cardiac surgery patients studied and a similar distribution was found in both analyzed groups of cardiac surgery patients. This distribution was not statistically significant.

\section{Nursing workload on the NAS scale}

Our analysis showed statistically significant differences in NAS scores between day duty day 0 and the other day and night duty days. The NAS score was significantly higher for day duty than during the days that followed the procedure. Statistical significance applied to all duty days (Fig. 1).

On duty days following the procedure, significant differences were found in NAS scores between day and night duty days. On day 0 the NAS score on night duty was significantly higher than the NAS score on night duty (Fig. 2).

On day duty day 1, the NAS score was below the norm, but significantly lower for ERAS protocol patients than for standard anaesthetised patients $(p<0.000001)$. On day duty day 2, the NAS score was below the norm, but significantly lower for ERAS protocol patients than for standard anaesthetised patients $(p<0.000001)$. As the table below shows, NAS is therefore a good instrument to appraise the impact of the implementation of a new technology/procedure in the ICU, at least concerning the cost and the consumption of the nursing resource (Table 1$)$. 


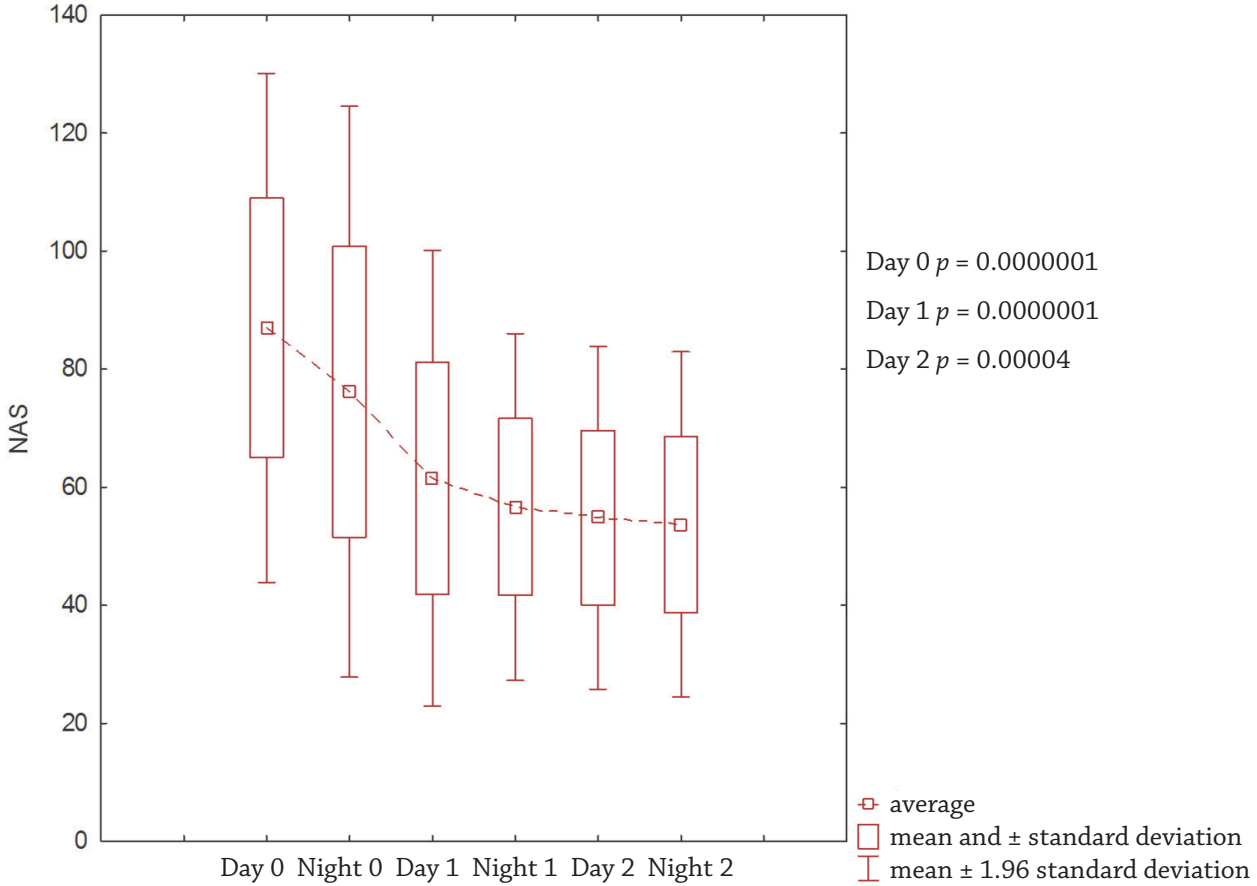

Fig 1. A comparison of average NAS scores for night and day nursing duties on individual days. $p$ - significance level

$$
\text { - day duty night duty }
$$

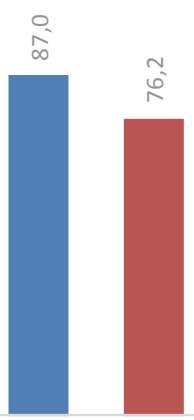

DAY 0

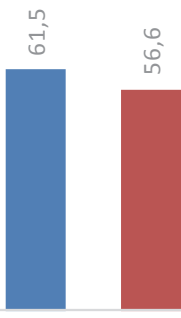

DAY 1

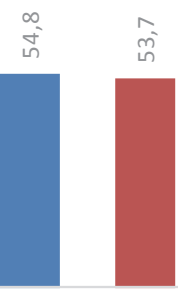

DAY 2

Fig. 2. A comparison of average NAS scores for night and day nursing duties on individual days. $p$ - significance level

Table 1. Comparison of patient results in both anesthesia groups on subsequent days

\begin{tabular}{|c|c|c|c|c|c|c|}
\hline \multirow{2}{*}{ NAS } & & \multicolumn{2}{|c|}{ ERAS protocol } & \multicolumn{2}{|c|}{ Standard anaesthesia } & \multirow{2}{*}{$p$} \\
\hline & & Medium No. Pts & Mean NAS Score & Medium No. Pts & Mean NAS Score & \\
\hline \multirow{2}{*}{ Day 0} & day duty & 50 & $67.5+2.93$ & 50 & $106.5+13.17$ & 0.000001 \\
\hline & night duty & 50 & $54.9+2.83$ & 50 & $97.5+18.18$ & 0.000001 \\
\hline \multirow{2}{*}{ Day 1} & day duty & 2 & $48.8+2.85$ & 50 & $74.5+20.76$ & 0.000001 \\
\hline & night duty & 1 & $47.9+2.83$ & 50 & $65.4+16.98$ & 0.000001 \\
\hline \multirow{2}{*}{ Day 2} & day duty & 1 & $48.6+2.0$ & 31 & $62.9+17.52$ & 0.000001 \\
\hline & night duty & 1 & $46.2+0.5$ & 31 & $61.2+18.33$ & 0.000001 \\
\hline \multirow{2}{*}{ Day 3} & day duty & - & - & 16 & $61.2+18.33$ & \\
\hline & night duty & - & - & 16 & $5 ., 9+2.83$ & \\
\hline
\end{tabular}




\section{Discussion}

Our study explored how the type of anaesthesia influenced the nursing workload at ICUS. For this purpose, we used the NAS scale. The NAS scale was first published in 2003 by Miranda et al. (Miranda et al., 2003). In 2007 this scale was validated for Polish purposes by Dyk and Cudak (2008). As part of their study, they analysed five intensive care units in Poland. Three of them were secondary referral hospitals, while two were tertiary referral hospitals. The study covered a group of 314 atients hospitalised at ICUs (Dyk and Cudak, 2008). They analysed the data of 100 patients of a tertiary referral hospital. The data were collected for 7 months. Male participants were in the majority ( $52 \%$ vs. $48 \%$ female participants). They were randomly assigned to ERAS anaesthesia (50\%) and, also randomly, to standard anaesthesia (50\%). The average age of patients in the Piroze ICU was $60.3 \pm 13$ years (Davierwala et al., 2013). In our study patients were aged 18 to 81 .

The study revealed that the nursing workload decreased gradually over the ICU hospitalisation period. The highest workload was found on day 0 . A prolonged ICU hospitalisation involved a range of adverse events such as: hospital-acquired infections and mental strain on the personnel and patients. Bernat Adell et al. (2005) and Li et al. (2018) have proven that a strong relationship exists between the NAS workload and the hospitalisation of patients.

In our study, on day 0 the NAS score on day duty was significantly higher than the NAS score on night duty. This could be explained by the activities performed by nurses during the admission of post-operative patients (arterial-blood gas tests, laboratory tests, medical documentation, blood and blood product transfusions in cases of increased drainage, follow-up tests every hour for the first six hours after the surgery). Keene and Cullen (1983) also noted this relationship in their studies.

In our study, we noted that the nurses who provided care to standard anaesthetised patients scored above 100 on the NAS scale. This means that more than one nurse should handle the care of one patient. In the case of ERAS protocol patients, the score was lower by approximately a half, meaning that the nurses who were responsible for these patients could spend half of their working time helping in providing care to other patients. Due to its design and items, the NAS scale allows a more detailed investigation of nursing activities, while also providing more information on patients and the workload they require.

The scales which measure the nursing workload involve certain limitations, and these have significant implications for the studies. The NAS scale covers over $40 \%$ more nursing activities than the TISS-28 and NEMS scales. Measuring typically nursing-related activities, the scale provides what was missing in other scales, and what limited the applicability of these scales in workload studies (Hugonnet et al., 2007; Miranda et al., 1996; Penoyer, 2010). The average time it takes a nurse to complete the nursing intervention questionnaire is $5-6 \mathrm{~min}-$ utes. Hence, it could be an everyday tool to measure demand for the nursing personnel. The NAS scale relates not only to clinical activities, but also to the care activities involving nurses. A systematic assessment of the care provided by therapeu- tic teams to patients helps to improve the overall healthcare system and its individual components (Wasilewski, 2008). Branch-Elliman et al. (2013) conducted studies which found that nurses did not delay their tasks due to patients requiring an increased workload. For $29 \%$ of the respondents, some delays were attributable to factors unrelated to the patient's body (e.g. ventilator set-up).

Our study showed that despite the ERAS protocol being in place, more nurses were needed to staff ICUs. Although nurses devoted an average of half their working time to ERAS patients, it should be noted that some standard anaesthetised patients required about $100 \%$ of nursing work time. Studies by researchers from other countries found that an average of $72.8 \%$ of ICU nurses were given an excessive workload (Camuci et al., 2015; Giakoumidakis et al., 2012; Nogueira et al., 2013; Stafseth et al., 2011). The maximum workload was recorded in Norway at $101.8 \%$. Average workloads were recorded in Poland (83.0\%), Greece (64.59\%), Egypt (57.1\%), Brazil (54.0\%) and the Netherlands (51.0\%). According to other studies, ICU workload depends on both the specific conditions of the ICU and the patients' conditions [33, 34, 35, 36]. The leading studies on nursing workload were conducted by Needelman (Cullen et al., 1974). In intensive care, patient qualification for surgery and nursing workload reduction are both important aspects of patient care (Frutiger, 1999; Keene and Cullen, 1983; Miranda et al., 1996; Norrie, 1997). ICU nursing activities accounted for similar workloads on the NAS scale. Harrison and Nixon compiled studies which used data on the time spent by nurses on individual activities (Norrie, 1997). The largest percentage of their work time was associated directly with providing care. Other studies found that the provision of direct care accounted for $50 \%$ of nursing work time, while $10 \%$ was spent on noncare duties. According to Norrie (1997), 60\% of nursing work time was spent on direct care, $22 \%$ on patient evaluation and $10 \%$ on indirect activities. Furthermore, in his study Harrison found that nurses spent $80 \%$ of their work time on patient evaluation, monitoring and position changes, and on keeping records of their nursing activities.

In global studies, we did not find information on the workload of nurses in anesthetized patients according to the ERAS protocol. There are studies on patient mortality and the workload of nurses (Margadant et al., 2020). However, there are no global reports on patient mortality and the workload of nurses in the ERAS group. This study is the first in the world.

\section{Conclusions}

The nursing workload associated with ERAS patients is lower than that associated with standard anaesthetised patients. The duration of both respiratory support and hospitalisation at ICUs depends on the type of anaesthesia. Statistically significant differences were found in NAS scores between care provided to ERAS patients and care provided to standard anaesthetised patients. The ERAS protocol has a positive effect on patient safety at all its stages.

\section{Conflict of interests}

The authors declare no conflict of interests. 


\section{Vliv protokolu „Enhanced Recovery After Surgery Protocol“ na pracovní zátěž zdravotních sester u kardiologických pacientů}

\section{Souhrn}

Cílem studie bylo porovnat pracovní zátěž sester u pacientů po operaci srdce s minimálním přistupem, standardní anestezií a podle protokolu ERAS. Byla použita kvantitativní popisná metoda. Studie zahrnovala skupinu 100 pacientů s onemocněním mitrální chlopně na kardiologické jednotce intenzivní péče (ICU) v Polsku. Výzkumný projekt trval 7 měsíců. Pracovní zátěž sester byla hodnocena v souladu s měřítky NAS. Průměrný věk studovaných pacientů byl $54,9 \pm 14,38$. Skupina pacientů zahrnovala 48 \% žen a 52 \% mužů.

Průměrná pracovní zátěž sester ve skupině ERAS v NAS skoringu v den 0denní povinnosti byla $67,5 \pm 2,97$. Průměrná pracovní zátěž sester ve skupině ERAS v NAS skoringu v den 1 denní povinnosti byla $48,6 \pm 2,85$. Průměrná pracovní zátěž sester ve skupině ERAS v NAS skoringu ve 2 . den denní povinnosti byla 48,6 \pm 2 . Pacienti s anestezií podle protokolu ERAS vyžadovali méně práce než standardní pacienti s anestezií. Pracovní zátěž u pacientů s anestezií podle protokolu ERAS je ve srovnání s pracovní zátěží u standardních pacientů s anestezií nižší.

Klíčová slova: ERAS („Enhanced Recovery After Surgery Protocol“); NAS (Nursing activities score); zdravotní sestry

\section{References}

1. Aiken LH, Clarke SP, Sloane DM, Sochalski J, Silber JH (2002). Hospital nurse staffing and patient mortality, nurse burnout, and job dissatisfaction. JAMA 288(16): 1987-1993. DOI: 10.1001/jama.288.16.1987.

2. Aiken LH, Sermeus W, Heede KV, Sloane DM, Busse R, McKee M, et al. (2012). Patient safety, satisfaction and quality of hospital care: cross sectional surveys of nurses and patients in 12 countries in Europe and the United States. BMJ 20(344): 1-14. DOI: 10.1136/bmj.e1717.

3. Aiken LH, Sloane DM, Bruyneel L, Griffiths P, Sermeus W (2014). Staffing and education of nurses and hospital mortality in Europe - Authors' reply. Lancet 384(9946): 851-852. DOI: 10.1016/S0140-6736(14)61482-3.

4. Bernat Adell A, Abizanda Campos R, Cubedo Rey M, Quintana Bellmunt J, Sanahuja Rochera E, Sanchíz Muñoz J, et al. (2005) Nursing Activity Score (NAS). Our experience with a nursing load calculation system based on times. Enferm Intensiva 16(4): 164-173. DOI: 10.1016/s1130-2399(05)73403-9.

5. Branch-Elliman W, Wright SB, Gillis JM, Howell MD (2013). Estimated nursing workload for the implementation of ventilator bundles. BMJ Qual Saf 22(4): 357-361. DOI: 10.1136/bmjqs-2012-001372.

6. Bray K, Wren I, Baldwin A, St Ledger U, Gibson V, Goodman S, Walsh D (2010). Standards for nurse staffing in critical care units determined by: The British Association of Critical Care Nurses, The Critical Care Networks National Nurse Leads, Royal College of Nursing Critical Care and In-flight Forum. Nurs Crit Care 15(3): 109-111. DOI: 10.1111/j.1478-5153.2010.00392.x.

7. Camuci MB, Martins JT, Cardeli AAM, Robazzi M (2015). Nursing Activities Score: nursing work load in a burns Intensive Care Unit. Rev Latino Am Enfermagem 22(2): 325-331. DOI: 10.1590/0104-1169.3193.2419.

8. Cullen DJ, Civetta JM, Briggs BA, Ferrara LC (1974). Therapeutic intervention scoring system: a method for quantitative comparison of patient care. Crit Care Med 2(2): 57-60.

9. Davierwala PM, Seeburger J, Pfannmueller B, Garbade J, Misfeld M, Borger MA, Mohr FW (2013). Minimally invasive mitral valve surgery: "The Leipzig experience". Ann Cardiothorac Surg 2(6): 744-750. DOI: 10.3978/j.issn.2225319X.2013.10.14.

10. Dyk D, Cudak EK (2008). Zastosowanie skali czynności pielęgniarskich (Nursing Activities Score) do planowania obsad pielęgniarskich na oddziałach intensywnej terapii. Anestezjologia i Ratownictwo, 1: 70-75 (in Polish).
11. Frutiger A (1999). Qualitätssicherung in der Intensivmedizin: die Situation in der Schweiz. Schweiz Med Wochenschr 129: 1592-1599.

12. Giakoumidakis K, Baltopoulos GI, Charitos C, Patelarou E, Fotos NV, Brokalaki-Pananoudaki H (2012). Risk factors for increased in-hospital mortality: a cohort study among cardiac surgery patients. Eur J Cardiovasc Nurs 11(1): 23-33. DOI: 10.1016/j. ejcnurse.2010.09.005.

13. Hugonnet S, Uckay I, Pittet D (2007). Staffing level: a determinant of late onset ventilator - associated pneumonia. Crit Care 11(4): R80. DOI: 10.1186/cc5974.

14. Kane RL, Shamliyan TA, Mueller C, Duval S, Wilt TJ (2007). The association of registered nurse staffing levels and patient outcomes: systematic review and meta-analysis. Med Care 45(12): 1195-1204. DOI: 10.1097/MLR.0b013e3181468ca3.

15. Keene AR, Cullen DJ (1983). Therapeutic Intervention Scoring System: update 1983. Crit Care Med 11(1): 1-3. DOI: 10.1097/00003246-198301000-00001.

16. Li M, Zhang J, Gan TJ, Qin G, Wang L, Zhu M, et al. (2018). Enhanced recovery after surgery pathway for patients undergoing cardiac surgery: a randomized clinical trial. Eur J Cardiothorac Surg 54(3): 491-497. DOI: 10.1093/ejcts/ ezy100.

17. Margadant $\mathrm{C}$, Wortel S, Hoogendoorn M, Bosman R, Spijkstra JJ, Brinkman S, de Keizer N (2020). The Nursing Activities Score Per Nurse Ratio Is Associated With InHospital Mortality, Whereas the Patients Per Nurse Ratio Is Not. Crit Care Med 48(1): 126-127. DOI: 10.1097/ CCM.0000000000004005.

18. Miranda DR, de Rijk A, Schaufeli W (1996). Simplified Therapeutic Intervention Scoring System. The TISS - 28 items Results from a multicenter study. Crit Care Med 24(1): 64-73. DOI: 10.1097/00003246-199601000-00012.

19. Miranda DR, Moreno R, Iapichino G (1997). Nine equivalents of nursing manpower use score (NEMS). Intensive Care Med 23(7): 760-765. DOI: 10.1007/s001340050406.

20. Miranda DR, Nap R, de Rijk A, Schaufeli W, Iapichino G (2003). Nursing Activities Score. Crit Care Med 31(2): 374-382. DOI: 10.1097/01.CCM.0000045567.78801.CC.

21. Nogueira LS, Koike KM, Sardinha DS, Padilha KG, de Sousa RMC (2013). Nursing workload in public and private intensive care units. Rev Bras Ter Intensiva 25(3): 225-232. DOI: 10.5935/0103-507X.20130039.

22. Norrie P (1997). Nurse's time management in intensive care. Nurs Crit Care 2(3): 121-125.

23. Numata Y, Schulzer M, Van der Wal R, Globerman J, Semeniuk P, Balka E, Fitzgerald JM (2006). Nurse staffing levels and hospital mortality in critical care settings: literature 
review and meta-analysis. J Adv Nurs, 55(4): 435-448. DOI: $10.1111 / j .1365-2648.2006 .03941 . x$.

24. Penoyer DA (2010). Nurse staffing and patient outcomes in critical care: a concise review. Critical Care Medicine 38(7): 1521-1528. DOI: 10.1097/CCM.0b013e3181e47888.

25. Rafferty AM, Clarke SP, Coles J, Ball J, James P, Martin McKee, Aiken LH (2007). Outcomes of variation in hospital nurse staffing in English hospitals: cross-sectional analysis of survey data and discharge records. Int J Nurs Stud 44(2): 175-182. DOI: 10.1016/j.ijnurstu.2006.08.003.

26. Seago JA, Williamson A, Atwood C (2006). Longitudinal analyses of nurse staffing and patient outcomes: more about failure to rescue. J Nurs Admin 36(1): 13-21. DOI: 10.1097/00005110-200601000-00005.

27. Smereka J, Kiibler A (1998). Zalecenia Europejskiego Towarzystwa Intensywnej Terapii, Zespołu ds. Minimalnych wymagań dla Oddziałów Intensywnej Terapii. Medycyna Intensywna i Ratunkowa 1: 69-79 (in Polish).

28. Stafseth SK, Solms D, Bredal IS (2011). The characterisation of workloads and nursing staff allocation in intensive care units: a descriptive study using the Nursing Activities Score for the first time in Norway. Intens Crit Care Nur 27(5): 290-294. DOI: 10.1016/j.iccn.2011.07.003.

29. Wasilewski $\mathrm{T}$ (2008). Subiektywna ocena wybranych aspektów satysfakcji z pobytu w szpitalu pacjentów oddziałów zabiegowych. Pielęgniarstwo Chirurgiczne i Angiologiczne 3: 81-86.

30. Wołowicka L, Dyk D (2001). Leczenie usprawniające i pielęgnacja. In: Szulc R (Ed.). Usprawnianie lecznicze krytycznie chorych. Wrocław: Urban \& Partner (in Polish).

31. Wysokiński M (2006). Metody klasyfikacji pacjentów a zapotrzebowanie na opiekę pielęgniarską chorych hospitalizowanych na oddziałach intensywnej terapii. Rozprawa Doktorska, Academia Medicine. Lublin. Doctoral dissertation (in Polish).

32. Zingg W, Holmes A, Dettenkofer M, Goeting T, Secci F, Clack L, et al. (2015). Hospital organisation, management, and structure for prevention of health-care-associated infection: a systematic review and expert consensus. Lancet Infect Dis 15(2): 212-24. DOI: 10.1016/S1473-3099(14)70854-0. 